\title{
Use of Lemongrass (Cymbopogon citratus) Leaf Meal as a Natural Feed Additive on Growth Performance and Economics of Broilers
}

\author{
A. K. Parade, B. M. Thombre, R. A. Patil, P. V. Padghan, \\ B. S. Gaikwad and P. B. Meshram*
}

Department of Animal Husbandry and Dairy Science, College of Agriculture, Latur, India

*Corresponding author

\begin{abstract}
Keywords
Growth performance, Feed intake, Feed conversion ratio, Economics

Article Info

Accepted:

15 September 2019 Available Online:

10 October 2019 supplemented with 0.5 per cent, 1.00 per cent and 1.5 per cent lemongrass leaf meal, respectively. At the end of $6^{\text {th }}$ week average cumulative body weight $(\mathrm{g})$ in $\mathrm{T}_{1}, \mathrm{~T}_{2}, \mathrm{~T}_{3}$ and $\mathrm{T}_{4}$ were $2473.25,2632.50,2548.95$ and $2635.45 \mathrm{~g}$ per birds, respectively. The average cumulative body weight of broiler birds in the treatment groups $\mathrm{T}_{4}$ was significantly $(\mathrm{P}<0.05)$ higher as compared to those in $\mathrm{T}_{1}, \mathrm{~T}_{2}$ and $\mathrm{T}_{3}$ group. The total body weight gain at the end of sixth week is $2426.28,2585.10,2501.53$ and $2588.23 \mathrm{~g}$ per bird in treatments $T_{1}, T_{2}, T_{3}$ and $T_{4}$, respectively. The chicks in treatment groups $T_{2}, T_{3}$ and $T_{4}$ grew significantly $(\mathrm{P}<0.05)$ faster than $\mathrm{T}_{1}$ control group. The total feed consumption at the end of sixth week was $4715.28,4540.39,4448.66$ and $4400.63 \mathrm{~g}$ per bird in treatments $\mathrm{T}_{1}, \mathrm{~T}_{2}$, $\mathrm{T}_{3}$ and $\mathrm{T}_{4}$, respectively. Control group $\mathrm{T}_{1}$ consume significantly $(\mathrm{P}<0.05)$ more feed as compare to $\mathrm{T}_{4}, \mathrm{~T}_{2}$ and $\mathrm{T}_{3}$ group. Feed conversion ratio from first to sixth week ranged from 1.95 to 1.70 which was significantly $(\mathrm{P}<0.05)$ better in $\mathrm{T}_{4}(1.70)$ as compare to $\mathrm{T}_{2}(1.75)$, $\mathrm{T}_{3}$ (1.78) and $\mathrm{T}_{1}$ (1.95) control group. The results from the present study, it could be suggested that the use of LGLM as a feed additive at the level of 1.5 per cent as it proved be significantly better growth performance, feed intake and FCR and increase in cost of broiler production.
\end{abstract}

\section{A B S T R A C T}

A total of eighty, day old, broiler chicks (Vencobb-430) divided in four treatments of 20 chicks in each treatment with four replication of 5 chicks. The control $\left(\mathrm{T}_{1}\right)$ group was fed standard broiler ration and $\mathrm{T}_{2}, \mathrm{~T}_{3}$ and $\mathrm{T}_{4}$ group were provided same standard ration

\section{Introduction}

Indian poultry industry opportunities are unlimited because India has population of approximately 1.25 billion peoples with GDP growth rate about 9 per cent which is one of the biggest consumer markets in world. Poultry contribute about 15 per cent of total food energy and 5 per cent of dietary protein. Poultry is major source of meat in India. Its share in total meat consumption is 28 percent, as against 14 percent 10 to 28 years ago. It has outpaced its two competitors-beef or veal and buffalo meat. High mutton prices, religious restrictions on beef, pork and the limited availability of fish outside coastal region have 
all helped to make poultry meat the most preferred and most consumed meat in India (Mehta and Nambiar, 2008) Nowadays, increasing of consumer awareness for safety poultry products and from stable to table approach tended the consumer's preferences towards healthy animal products. One of the feed additives used to increase the performance of poultry are herbs.

Lemongrass is an aromatic perennial tropical plant that can grow as high as 3.5 meters with long thin leaves. Lemon grass was originally found growing wild in India. It produces a network of roots and rootless that rapidly exhausts the soil. In human medicine, Lemongrass has the following therapeutic properties: analgesic, antidepressant, antimicrobial, antipyretic, antiseptic, bactericidal, diuretic, fungicidal, insecticidal and nervous system sedative tonic (Mmereole 2010). Lemongrass (Cymbopogon citratus) contains flavonoids, phenolic compounds, terpenoids and essential oils (such as citral $\alpha$, citral $\beta$, nerol geraniol, citronellal, terpinolene, geranyl acetate, myrecene and terpinol methylheptenone) which may be responsible for its different biological activities such as anti-bacterial, anti-diarrheal, anti-fungal antioxidants, and as a growth promoter (Sariozkhan et al., 2016). Chemical composition and anti-bacterial activity of aqueous extract of Cymbopogon citratus leaves were studied. Moisture, Crude protein, Crude fiber and Carbohydrate contents were $12.36 \%, 15.68 \%, 27.72 \%$ and $29.58 \%$ respectively. Phosphorus was found to be the most abundant $(15.58 \mathrm{mg} / 100 \mathrm{~g})$ followed by Potassium (8.60mg/100g). Zinc an important microelement was present in considerable amount $(0.93 \mathrm{mg} / 100 \mathrm{~g})$ (Oloyede 2009). The herbal growth promoters for poultry can create optimum condition for normal vigorous growth by acting various ways. The successful use of herbal growth promoter will fetch more profit to poultry farmer by efficient conversion of feed consumed to body constituents. Lemon grass leaf meal may also improve feed conversion ratio and so help reduce feed costs in broiler production especially as it is quite inexpensive and it is abundantly available (Mmereole 2010).

\section{Materials and Methods}

Eighty, day old, commercial straight run broiler chicks of 'vencobb 430' strain were obtained from Huma hatcheries, Latur (Maharashtra). All the experimental chicks were individually weighed, wing banded and then randomly distributed in to four treatments of 20 chicks with four replication of 5 chicks in each treatment on similar body weight basis.

The dietary treatments $T_{1^{-}} 100$ parts of standard broiler ration without supplement (control sample), $\mathrm{T}_{2^{-}} 99.5$ parts of standard broiler ration +0.5 lemongrass leaf meal, $\mathrm{T}_{3^{-}}$ 99.00 parts of standard broiler ration +1.00 parts of lemongrass leaf meal and $\mathrm{T}_{4^{-}}-98.5$ part standard broiler ration +1.5 parts of lemongrass leaf meal.

All the broiler chicks were fed with ground maize first two days of age. Chicks feed standard feed purchased from market for three periods of 2-10 days birds fed with pre-starter, 11-21 days birds fed with broiler starter and 22-42 days birds fed with broiler finisher. The diets were fed ad-libitum to experimental groups by adding required amount of lemongrass leaf meal as per treatment. The per cent ingredient composition of experimental broiler ration that is for pre-starter, starter and finisher in Table 1.

\section{Chemical analysis}

The chemical analysis of the experimental broiler ration was carried out as per A.O.A.C. (1995) for all the proximate principles. 


\section{Statistical analysis}

The treatment wise data on cumulative body weight gain in body weight, feed consumption and feed conversion ratio, water intake and blood serum constituents were subjected to analysis of variance of complete randomized design (Snedecor and Cochran,1982).

\section{Results and Discussion}

\section{Growth performance}

The mean average cumulative body weight of broilers in the treatment groups $\mathrm{T}_{4}$ was significantly $(\mathrm{P}<0.05)$ higher as compared to those in $T_{1}, T_{2}$, were as at par with $T_{4}$ group. It could be seen that highest cumulative body weight of $2635.45 \mathrm{~g}$ obtained in $\mathrm{T}_{4}$ group broiler receiving 1.5 per cent lemongrass leaf meal followed by $2632.50 \mathrm{~g}$ with 0.5 per cent in $\mathrm{T}_{2}$ and $2548.95 \mathrm{~g}$ with 1 per cent in $\mathrm{T}_{3}$ and lowest cumulative body weight i.e. $2473.25 \mathrm{~g}$ in $\mathrm{T}_{1}$ control at the end of $6^{\text {th }}$ week.

The results of the present study ware similar with Mmereole (2010) who observed that inclusion of Cymbopogon citratus leaf meal in poultry diet resulted in a significantly $(\mathrm{P}<0.05)$ higher body weight and body weight gain when compared to the control diet. Similar trend was also observed by Tiwari et al., (2018) who found that total weight gain of birds was higher in experimental birds receiving lemongrass oil as compared to control group without lemongrass oil. Results in body weight gain are given in broiler birds under four different treatments during each week revealed significant $(\mathrm{P}<0.05)$ difference during all the weeks. At the end of sixth week it was seen from the Table 2 that the total gain in body weight of bird amon $g$ treatment groups $T_{4}$ and $T_{2}$ was significantly superior $(\mathrm{P}<0.05)$ as compared to $\mathrm{T}_{1}$ control group and $\mathrm{T}_{3}$ group. Average gain in body weight in $\mathrm{T}_{4}$ did differed significantly with $\mathrm{T}_{2}$ group. The treatment $\mathrm{T}_{1}$ control (2426.28 g) was significantly lower as compared to all the treatments i.e. $\mathrm{T}_{2}(2585.10 \mathrm{~g}), \mathrm{T}_{3}(2501.53 \mathrm{~g})$ and $\mathrm{T}_{4}(2588.23 \mathrm{~g})$. Whereas at par with $\mathrm{T}_{3}$ $(2501.53 \mathrm{~g})$

The results obtained in the study corresponds with the results of Mmereole (2010) who observed that inclusion of Cymbopogon citratus leaf meal in poultry diets resulted in significantly $(\mathrm{P}<0.05)$ higher body weight and body weight gain as compared to control diet. Tiwari et al., (2018) also observed similar trend and higher body weight gain where lemongrass oil was included $400 \mathrm{ml} / 100 \mathrm{~kg}$ feed compared to the control group. Takeli et al., (2011) also noted that chicks fed on diet with supplemented LGO recorded significantly heavy weight gain. These results are in agreement with Takeli et al., (2011) and Mukhtar et al., (2012) where their experiment revealed significantly improve in body weight gain for broilers fed diets supplemented with various levels of LGO as compared with the control group. Khattak et al., (2014) reported that the inclusion of lemongrass leaf meal in the broilers diet improves the body weight gain with positive effects on feed conversion ratio.

\section{Feed intake}

It could be seen that lowest feed consumption of $4400.63 \mathrm{~g}$ was obtained in $\mathrm{T}_{4}$ group broilers receiving 1.5 per cent lemongrass leaf meal followed by $4448.66 \mathrm{~g} \mathrm{~T}_{3}, 4540.39 \mathrm{~g} \mathrm{~T}_{2}$ and the highest feed consumption i.e. $4715.28 \mathrm{~g}$ in $T_{1}$ at the end of $6^{\text {th }}$ week. It showed that the birds fed with lowest level of lemongrass leaf meal and highest feed consumption rate in the broiler birds. It was concluded from Table 3 that there were no significant differences among the all treatment groups except third and fourth week where as significant differences were recorded for total feed consumption towards end of experiment. The 
lemongrass leaf meals are generally tangy taste without the bitterness of lemon, therefore, the inclusion of LGLM in the diets could have resulted in reduced palatability and does reduced feed intake of the broiler diets. The present studies are contrary to findings of Tiwari et al., (2018) reported that lemongrass leaf meal supplementation in broiler chicken significantly increased feed consumption. Takeli et al., (2011) who revealed that chicks fed on diet with antibiotic and those supplemented with LGO recorded significantly heavy weight gain, this improve may be attributed to the increase in total feed consumption.

The similar results were found by Mukhtar et al., (2012) who reported that broilers fed diets supplemented with various levels of LGO consumed significantly more amount of feed compared to the broilers fed control NC diet.

Chioma et al., (2017) reported that the contrary results on performance parameters of feed intake are significant $(\mathrm{P}<0.05)$ from the control diet but no significance different among the treatments $(\mathrm{P}<0.05)$. It can therefore conclude that Cymbopogon citratus are effective as toxin binder in poultry feed without any negative implication on both internal and external characteristics of birds. Mukhtar et al., (2012) resulted that the addition of LGO significantly improved $(\mathrm{P}<0.05)$ feed intake of broiler chicks as compared to the control group while non significant $(\mathrm{P}>0.05)$ differences were noted among broilers fed on diets supplemented with LGO and antibiotic supplemented groups, respectively.

\section{Feed conversion ratio}

The average feed conversion ratio from first to sixth week ranged from 1.95 to 1.70 which was significantly $(\mathrm{P}<0.05)$ better feed conversion ratio of 1.70 obtained in $\mathrm{T}_{4}$ group broilers receiving 1.5 per cent lemongrass leaf meal followed by 1.75 with 0.5 per cent in $T_{2}$, 1.78 in $\mathrm{T}_{3}$ group receiving 1.0 per cent lemongrass leaf meal and poor in feed conversion i. e. 1.95 in $T_{1}$ control at the end of $6^{\text {th }}$ week. It shows that 1.5 per cent level of lemongrass leaf meal give better feed conversion ratio in broiler birds.

Chioma et al., (2017) who reported that the performance parameters of feed conversion ratio are significant $(\mathrm{P}<0.05)$ from the control diet but no significant difference among the treatment $(\mathrm{P}<0.05)$. The result of present study support the findings of similarly Mukhtar et al., (2012) reported that supplementation of $0.5 \%, 1 \%$ and $1.5 \% \mathrm{LG}$ oil is significantly improve in feed conversion ratio for broilers fed diets supplemented with various levels of LGO as compared with control group.

The present results obtained are contrary to the finding of Sariozkan et al., (2016) who reported the feed conversion ratio were not affected by lemongrass supplementation, In $3 \%$ supplemented group, ratio decreased $(\mathrm{P}<0.05)$ (Table 4).

Thayalini et al., (2011) also reported that supplementation of $2 \%$ LG leaf to diet did not affect the feed conversion ratio in broilers. Similarly, supplementation of $1.5 \%$ and $3 \%$ LG leaf did not affect the feed conversion ratio of quail; whereas Mmereole (2010) reported that $1 \%$ LG leaf supplementation to broiler diet improved the feed conversion ratio.

\section{Economics of broiler production}

Results of economical analysis of including lemongrass leaf meal in broilers diets are presented in Table 5. The economical values were calculated according to prevailing local market (selling) prices at the experimental time (2019). 
Table.1 Chemical composition of experimental broiler ration

\begin{tabular}{|c|c|c|c|c|}
\hline Sr. & & \multicolumn{3}{|c|}{ Per cent in ration } \\
\cline { 3 - 5 } No. & Nutrients & Pre-starter & Starter & Finisher \\
\hline $\mathbf{1}$ & Crude protein & 23.35 & 21.64 & 20.20 \\
\hline $\mathbf{2}$ & Crude fibre & 3.92 & 3.96 & 3.99 \\
\hline $\mathbf{3}$ & Ether extract & 4.95 & 5.08 & 5.12 \\
\hline $\mathbf{4}$ & Total ash & 6.2 & 6.1 & 5.93 \\
\hline $\mathbf{5}$ & Acid insoluble ash & 1.57 & 1.60 & 1.62 \\
\hline $\mathbf{6}$ & Nitrogen free extract & 61.58 & 63.22 & 64.76 \\
\hline $\mathbf{7}$ & Metabolizable energy $(\mathrm{kcal} / \mathrm{kg})$ & 2982.5 & 3065.7 & 3198.8 \\
\hline $\mathbf{8}$ & E/P ratio & $127.73: 1$ & $141.66: 1$ & $158.35: 1$ \\
\hline
\end{tabular}

Table.2 Body weight gain of broiler chicks as affected by addition of lemongrass leaf meal

Items

LGLM level

\begin{tabular}{lcccccc} 
& $\mathrm{T}_{1}(0 \%)$ & $\mathrm{T}_{2}(0.5 \%)$ & $\mathrm{T}_{3}(1 \%)$ & $\mathrm{T}_{4}(1.5 \%)$ & $\mathrm{SE}$ & $\mathrm{CD}$ at 5\% \\
\hline $1^{\text {st }}$ week & 119.03 & 123.39 & 102.08 & 150.61 & 14.75 & $\mathrm{NS}$ \\
\hline $2^{\text {nd }}$ week & 196.00 & 211.22 & 199.50 & 217.42 & 22.96 & $\mathrm{NS}$ \\
\hline $3^{\text {rd }}$ week & $320.25^{\mathrm{a}}$ & $436.49^{\mathrm{b}}$ & $450.67^{\mathrm{b}}$ & $468.74^{\mathrm{b}}$ & 23.93 & $*$ \\
\hline $4^{\text {th }}$ week & 532.25 & 515.00 & 485.33 & 487.73 & 18.15 & $\mathrm{NS}$ \\
\hline $5^{\text {th }}$ week & 609.78 & 611.00 & 590.65 & 606.68 & 20.48 & $\mathrm{NS}$ \\
\hline $6^{\text {th }}$ week & 648.98 & 688.00 & 673.30 & 657.05 & 25.09 & $\mathrm{NS}$ \\
\hline Total & $2426.28^{\mathrm{a}}$ & $2585.10^{\mathrm{a}}$ & $2501.53^{\mathrm{ab}}$ & $2588.23^{\mathrm{b}}$ & 33.72 & $*$ \\
\hline
\end{tabular}

(Significant $(\mathrm{P}<0.05)$ means under each class in the same column with different superscripts differ significantly)

Table.3 Feed intake of broiler chicks as affected by addition of lemongrass leaf meal

\begin{tabular}{lcccccc}
\hline Items & \multicolumn{7}{c}{ LGLM levels } \\
\hline & $\mathrm{T}_{1}$ & $\mathrm{~T}_{2}$ & $\mathrm{~T}_{3}$ & $\mathrm{~T}_{4}$ & & \\
\hline & $(0 \%)$ & $(0.5 \%)$ & $(1 \%)$ & $(1.5 \%)$ & $\mathrm{SE}$ & $\mathrm{CD}$ at $5 \%$ \\
\hline $1^{\text {st }}$ week & 138.76 & 124.75 & 141.30 & 156.41 & 8.36 & $\mathrm{NS}$ \\
\hline $2^{\text {nd }}$ week & 341.04 & 307.70 & 297.35 & 320.06 & 20.59 & $\mathrm{NS}$ \\
\hline $3^{\text {rd }}$ week & $726.82^{\mathrm{b}}$ & $622.98^{\mathrm{a}}$ & $648.50^{\mathrm{a}}$ & $651.67^{\mathrm{a}}$ & 17.74 & $*$ \\
\hline $4^{\text {th }}$ week & $1135.72^{\mathrm{b}}$ & $1099.56^{\mathrm{b}}$ & $1059.73^{\mathrm{ab}}$ & $1013.17^{\mathrm{a}}$ & 23.70 & $*$ \\
\hline $5^{\text {th }}$ week & 1117.17 & 1140.71 & 1092.70 & 1102.68 & 23.29 & $\mathrm{NS}$ \\
\hline $6^{\text {th }}$ week & 1255.77 & 1244.70 & 1209.20 & 1156.64 & 32.38 & $\mathrm{NS}$ \\
\hline Total & $4715.28^{\mathrm{b}}$ & $4540.39^{\mathrm{ab}}$ & $4448.66^{\mathrm{ab}}$ & $4400.63^{\mathrm{a}}$ & 59.22 & $*$ \\
\hline
\end{tabular}

(Value superscripted differently, differs significantly $(\mathrm{P}<0.05)$ within a column) 
Table.4 Effect of dietary lemongrass leaf meal on feed conversion ratio of broiler chicks

\begin{tabular}{|c|c|c|c|c|c|c|}
\hline \multirow[t]{2}{*}{ Items } & \multicolumn{6}{|c|}{ LGLM levels } \\
\hline & $\mathrm{T}_{1}$ & $\mathrm{~T}_{2}$ & $\mathrm{~T}_{3}$ & $\mathrm{~T}_{4}$ & & \\
\hline & $(0 \%)$ & $(0.5 \%)$ & $(1 \%)$ & $(1.5 \%)$ & SE & $\mathrm{CD}$ at $5 \%$ \\
\hline $1^{\text {st }}$ week & 1.17 & 1.01 & 1.38 & 1.04 & 0.03 & NS \\
\hline $2^{\text {nd }}$ week & 1.74 & 1.45 & 1.49 & 1.47 & 0.09 & NS \\
\hline $3^{\text {rd }}$ week & $2.27^{b}$ & $1.42^{\mathrm{a}}$ & $1.44^{\mathrm{a}}$ & $1.39^{\mathrm{a}}$ & 0.03 & $*$ \\
\hline $4^{\text {th }}$ week & 2.14 & 2.13 & 2.18 & 2.07 & 0.04 & NS \\
\hline $5^{\text {th }}$ week & 1.83 & 1.86 & 1.85 & 1.81 & 0.02 & NS \\
\hline $6^{\text {th }}$ week & 1.96 & 1.80 & 1.79 & 1.76 & 0.05 & NS \\
\hline Total & $1.95^{\mathrm{b}}$ & $1.75^{\mathrm{a}}$ & $1.78^{\mathrm{a}}$ & $1.70^{\mathrm{a}}$ & 0.03 & $*$ \\
\hline
\end{tabular}

$\mathrm{NS}=$ no significant difference $(\mathrm{P}>0.05) \quad$ *Significant difference $(\mathrm{P}<0.05)$

Table.5 Economics of broiler production per bird

\begin{tabular}{|c|c|c|c|c|}
\hline \multirow[t]{2}{*}{ Particular } & \multicolumn{2}{|c|}{ LGLM levels } & & \\
\hline & $\mathrm{T}_{1}$ & $\mathrm{~T}_{2}$ & $\mathrm{~T}_{3}$ & $\mathrm{~T}_{4}$ \\
\hline & $(0 \%)$ & $(0.5 \%)$ & $(1 \%)$ & $(1.5 \%)$ \\
\hline Cost of day old chicks (Rs.) & 45 & 45 & 45 & 45 \\
\hline Lemongrass consumed per bird (g) & 0 & 15.35 & 22.24 & 33.00 \\
\hline Cost of Lemongrass (₹ /g) & 0 & 0.28 & 0.28 & 0.28 \\
\hline Cost of Lemongrass (Rs.) & 0 & 3.18 & 6.23 & 9.24 \\
\hline Avg. Total feed consumed per bird (g) & 4715.28 & 4540.39 & 4448.78 & 4400.63 \\
\hline Cost of feed (₹ /Kg) & 28.9 & 28.9 & 28.9 & 28.9 \\
\hline Cost of feed consumed per bird & 136.27 & 134.21 & 128.56 & 127.18 \\
\hline Total cost of feed consumed per bird ₹ & 136.27 & 137.39 & 134.79 & 136.42 \\
\hline Avg. Body weight gain at the end of & 2426.28 & 2585.10 & 2501.53 & 2588.23 \\
\hline \multicolumn{5}{|l|}{$6^{\text {th }}$ week $(g)$} \\
\hline Feed consumption per kg live weight $(\mathrm{g})$ & 1943.42 & 1756.37 & 1778.42 & 1700.25 \\
\hline Cost of feed per kg live weight gain (₹ ) & 56.16 & 50.68 & 51.40 & 49.14 \\
\hline Cost of medicine, vaccine and litter & 6 & 6 & 6 & 6 \\
\hline \multicolumn{5}{|l|}{ material per bird (₹) } \\
\hline Cost of Production per bird (₹ ) & 187.27 & 188.39 & 185.39 & 187.43 \\
\hline Avg. Price realized @ ₹ 90 Per kg live & 224.74 & 232.66 & 225.14 & 232.94 \\
\hline \multicolumn{5}{|l|}{ weight (₹ ) } \\
\hline Net profit per bird (14-13) ₹ & 37.47 & 43.61 & 39.35 & 45.52 \\
\hline
\end{tabular}


The data regarding average live body weight (g), average feed consumption (g), feed consumption per $\mathrm{kg}$ live weight gain, cost of feed (Rs.), total cost of feed (including cost of lemongrass used per $\mathrm{kg}$ of feed under different treatments), cost of feed per $\mathrm{kg}$ live weight gain and net profit per bird are given in Table 5. The observation from the following table was indicated that the performance of broilers in $\mathrm{T}_{4}$ group was superior to that of the control and other treatments and 1.5 per cent level of lemongrass leaf meal in broiler diet seems to be economical. This might be due to improved feed conversion efficiency on supplementation of lemongrass leaf meal and also due to rich nutrient content of lemongrass. These results were partially in agreement with Mukhtar et al., (2012) results of economical evaluation showed that the addition of dietary LGO improved the performance of broiler chicks and resulted in economical benefits compared to control and antibiotic groups.

The results of economical evaluations of the experimental diets showed that the supplementation of lemongrass leaf meal to broiler diets improved the performance of chicks and resulted economic benefits. The ratio of broilers fed with $1.5 \%$ LGLM was the highest although all chicks fed on different levels recorded high ratio of profits compared to control group these result were in agreement with findings of Mukhtar et al., (2012). Economically the addition of LGO improved the performance of broiler chicks and resulted in economic benefits Tiwari et al., (2018).

This study indicated that supplementation of lemongrass leaf meal powder at the difference levels of $0.5 \%, 1.0 \%$ and $1.5 \%$ in the broiler chick's diet. Inclusion of $1.5 \%$ lemongrass leaf meal powder in broiler ration was beneficial in improving live weight and weight gain and 1.5 percent LGLM in broiler diet improved FCR. The inclusion of 1.5 per cent of lemongrass leaf meal in broiler diet as a herbal feed supplement is economical. The feeding of lemongrass leaf meal is economical as it improved overall performance of broilers and increased margin of profit in broiler production. Addition of 1.5 per cent lemongrass leaf meal powder is economical.

\section{References}

A. O. A. C. 1995. Official Methods of Analysis, $16^{\text {th }}$ ed. Association of Official Analytical Chemist, Washington D. C.

Chioma G. O., Akinsoyinu O. A., Olumide M. D., Ajayi O. A., Ndubuisi-Ogbonna L. C., Akinboye O. E., Adeyeye J. A., AyoBello T. and Afodu O. J. 2017. Carcass and Performance Characteristics of Broiler Chickens Fed with Cymbopogon citratus Leaf Meal as Alternative to Mycotoxin binder. International J. of Agril. Sci. 6(4):018-023.

Khattak F., Ronchi A., Castelli P. and Sparks N. 2014. Effects of Natural Blend of Essential Oil on Growth Performance, Blood Biochemistry, Cecal Morphology and Carcass Quality of Broiler Chickens. J. of Poult. Sci. 93(6):132-137

Mehta R. and Nambiar R. G. 2008. The Poultry Industry in India. Poultry in the $21^{\text {th }}$ Century. 1-61.

Mmereole F. U. C. 2010. Effects of Lemmon Grass (Cymbopogon citratus) Leaf Meal Feed Supplement on Growth Performance of Broiler Chicks. International J. of Poult. Sci. 9(12):1107-1111.

Mukhtar A. M., Mohamed K. A., Amal O. A. and Ahlam A. H. 2012. Effect of Different Levels of Lemon Grass Oil (LGO) as a Natural Growth Promoter on the Performance, Carcass Yield and Serum 
Chemistry of Broiler Chicks. Egypt

Poult. Sci. 33(1): 1-7.

Oloyede O. I., 2009. Chemical Profile and Antimicrobial Activity of Cymbopogon citrates Leaves. J. of Natural Products. 2(23): 98-103.

Sariozkan S., Konca Y., Kocaoglu B., Aktug M. K., Ozkan S. and Tugrul S. 2016. The Effect of Dietary Supplementation of Lemon Grass (Cymbopogon Citratus) on Performance, Carcass Quality, and Marketing of Quail (Coturnix Coturnix Japonica). J. Scientific Works. Series C. Veterinary Med. 63(1): 98-103.

Snedecor G. W. and Cochram W. G. 1982. Statistical Methods. $6^{\text {th }}$ Edition, Oxford and IBH Publishing co. Culcutta, Bombay and Delhi. Pp. 168181.

Takeli A. Kutlu H. R. And Celik 1. 2011.
Effect of Zingiber officinalis and Propolis Extract on the Performance, Carcase and Some Blood Parameters of Broiler Chicks. Current Res. in Poult. Sci. 1(1): 12-33.

Thayalani K., Shanmugavelu S., Saminathan P. M., Masidayu M. S., Nor I. Y., Zainuddin H., Nural A. C. and Wong H. K. 2011. Effect of Cymbopogan citrates Leaf and Zingiber officinale Rhizome Supplementation on Growth Performance, Ideal Morphology Lactic Acid Concentration in Broiler. Mal. J. Anim. Sci. 14(8): 43-49.

Tiwari M. R., Jha P. K., Sah B., Kunwar G. and Jha A. K. 2018. Performance of Lemongrass (Cymbopogon citrates) Oil as Growth Promoter in Broiler. Bang. J. Anim. Sci., 47(2): 85-91.

\section{How to cite this article:}

Parade, A. K., B. M. Thombre, R. A. Patil, P. V. Padghan, B. S. Gaikwad and Meshram, P. B. 2019. Use of Lemongrass (Cymbopogon citratus) Leaf Meal as a Natural Feed Additive on Growth Performance and Economics of Broilers. Int.J.Curr.Microbiol.App.Sci. 8(10): 18421849. doi: https://doi.org/10.20546/ijcmas.2019.810.214 